\title{
Scope of E-Commerce over Petroleum Products with Portable Refuellers in Succeeding Decades
}

Keerthika $R^{*}$ and Anli Suresh ${ }^{\dagger}$

\begin{abstract}
Petroleum and diesel products can be obtained in specialised refuellers like, 'Mini and Mobile Petrol Pumps' by placing orders on e-commerce platforms on a pre-booking basis. Mobile applications, home deliveries, online payments are the aid of the digital market. The concept of delivering petrol and diesel products to your doorstep with the help of applications like "My Petrol Pump" and "Book My Petrol" have come into the industry recently. This paper examines the promotion of the home delivery of petroleum products on e-commerce platforms and assesses customer's acceptability of the technology.
\end{abstract}

Keywords: E-Commerce, Online Market, Petroleum Refuellers

\section{Introduction}

The trend of e-commerce, a new phase in the commercial outlet started off in the field of oil and natural gas. Gradually, they started extending and establishing their imprints on food, clothing and so on. The study focuses on whether the topmost marketing platform of the modern era, e-commerce, leads the same grandness in "petroleum products" or whether it results in the same turnover as it scoped for other industries. The end users seem to welcome

"Madras Christian College, Chennai, India;

keerthikaravikumar7@gmail.com

† Department of Commerce, Madras Christian College, Chennai, India; anli.sgain@gmail.com 
"portable petroleum pumps" which are home delivered via ecommerce platforms. This innovation not only manages to impress the market but also helps in achieving the target.

\section{Petroleum Products}

Petrol has become an indispensable part of our day-to-day life. Transport has been an essential aspect of human civilization. The demand for sophistication and luxury has made a wide impact on the social lives of people. Individual use and ownership of cars, motorbikes and many more have created an increased demand for petrol. Further, with an increase in luxury, the numbers of vehicles on the road are also on the rise. This results in traffic and environment pollution apart from the petrol crisis, causing a shortage of the non-renewable resource which can be extracted only once. The reasons for the imbalance can be varied: over-intake, dated infrastructure, choke factor disruption, bottlenecks at oil refineries, or even port facilities that limit gas supply.

\section{E-Commerce}

Businesses in the twenty-first century are flourishing due to the internet. Nowadays, business firms can share product data, information, advertisements, new business strategies and products, new product unveiling date and so on with other businesses (B2B) or customers (B2C) almost instantly. The businesses are using the internet to sell their products. Oil, natural gas and petrochemical industries have an important role to play in the global energy market. Information Technology has had a strong impact on the petroleum industry in multiple ways and takes the benefits of ecommerce platform. Information Technology infrastructure and the internet can support the interchange of information between the divisions of the oil and gas industry. This paper optimises ecommerce and door delivery of petroleum product along with its related products, their scope in advance future, and the customer acceptability of the technology with the anywhere anytime phenomena. Further, it also looks into the design of portable refuel petrol pumps for the vehicle as well as the challenges, restraints, and risks factors of market feasibility. 


\section{Literature Review}

The article released by Zee Biz Web Team on 27 March 2018 on "Now get fuel delivered to your doorstep; all you need to know" has stated how the government and oil dealers have taken new steps in the distribution of oil products by implementing ecommerce with the initial step of door delivery of petroleum products anywhere anytime. This mobile delivery of petrol and diesel was taken as the pilot study in Pune. The e-commerce platform, "my petrol.com" had taken the initiative to deliver petrol/diesel at the location specified with specialized refuellers and other features available in online stores to provide customers in-time service.

Kavitha and Mary (2018) conducted research on customer perception towards the service quality of retail petrol outlets. The results show that the demographic factors like age, gender, education have an association with services provided in the retail outlets. However, other factors like occupation and monthly income do not affect the services of the retail outlet. Jacob (2017) in her article in Business Standard titled "Petrol, diesel home delivery: Soon, fuel at your doorstep on online booking" mentions how the government has roped in e-commerce platforms for oil and gas industry, and that many petroleum companies will soon be leading their business online as reportedly stated by Petroleum Minister, Dharmendra Pradhan in a meeting held in Srinagar India. Online fuel booking will cut down the long line in petroleum retail outlets, increase digital transactions, and help maintain proper accounting with door delivery and portable petroleum stations.

Chetan Kumar and Sunil Prasad (2017) in their article, "Bengaluru firm 1st in India to deliver diesel at home" mentions Bengaluru as the first city to implement the 'doorstep delivery' in petroleum with a portable pump carrying 950 litres along with a fixed delivery charge. The innovation was initiated by "my petrol pump" e-commerce platform and the portable pump carried all safety measures specially fabricated by a firm approved by the Petroleum and Explosives Safety Organization that made doorstep delivery in oil and gas industry possible. 
Kumari and Devi (2016) based their research on consumer behaviour towards retail petrol outlet services in Coimbatore. Their finding states that the relationship between customer behaviour towards the petroleum retail outlet was moderate. The research also states that there is no association between customer satisfaction and service utilisation of the customer.

\section{Statement of the Problem}

Emerging techno advanced design in oil and natural gas required more attention for overpopulated country therefore, the issues with safety and hazards need deeper evaluation.

Safety risk: The concept of portable petroleum along with this innovation brings in questions of safety since natural gas is highly inflammable. It is feared that even the slightest negligence may lead to the loss of human lives

Traffic fear: The portable feature increases the risk of traffic jams since, with more bookings and orders, the number of vehicles delivering the order will increase on the road.

Increase in the price: The innovation with an uncertain future leaves suspicion on pricing variation or price fluctuation.

Possibility: The portable petrol pump idea is experimental and has met with failures in the past. Since the idea is a new phenomenon, it gives rise to new queries and uncertainty, increasing the suspicion and agitation on the same. Unfortunately, the turnover in the marketing era does not provide comfortable assurance over some considerable factors.

\section{Research Gap}

While this study makes a contribution to our understanding of the future role of the e-commerce market in petroleum products, the current marketing era of e-commerce has taken its first step in the natural gas arena on which the research and experiment are still in progress. 


\section{Research Methodology}

Table 1: Research Methods Adopted

\begin{tabular}{|l|l|}
\hline Research Design & $\begin{array}{l}\text { Descriptive, qualitative, investigative and } \\
\text { expressive research design }\end{array}$ \\
\hline Sampling Technique & Quota sampling \\
\hline Sampling Unit & $\begin{array}{l}\text { Information technology, marketing, retailer } \\
\text { sectors }\end{array}$ \\
\hline Sample Size & 130 \\
\hline Research Instrument & $\begin{array}{l}\text { A structured printed questionnaire with scored } \\
\text { using a five-point Likert scale }\end{array}$ \\
\hline Data Collection & $\begin{array}{l}\text { Personal visit to the respondent's organization } \\
\text { and interviews }\end{array}$ \\
\hline Statistical Techniques & $\begin{array}{l}\text { Explanatory statistics, factor analysis, ANOVA } \\
\text { and chi-square. }\end{array}$ \\
\hline
\end{tabular}

\subsection{Hypothesis of the Study}

1. There is no significant difference between age and contemporary scope on home delivery of portable petroleum in the e-commerce platform.

2. There is no association between occupations and preference of home delivery of petroleum products.

\section{Research Objectives}

The main objective of the study is to explore the relationship between age and scope on home delivery portable petroleum in the e-commerce platform which comprises variables such as impulsive buying, home delivery as well as introducing technological marketing in chain stores in petroleum and natural gas industry. The secondary objective is to assess the customer acceptability of the technology with the abstraction of 'anywhere anytime phenomena' and understand the latitude of the design of portable refuel petrol pumps for vehicles in the later phase along with the challenges, restraints and risks factors of market feasibility. 


\subsection{Objectives}

- To study the latitude of the design of portable refuel petrol pumps, challenges, restraints and risks factors of market feasibility which threatens the innovative idea.

- To analyze customer acceptability of technology with the abstraction of 'anywhere anytime' phenomena. Further, the paper also explores whether the concept of portable refuellers has any correspondence with age and occupation of individuals.

\section{Data Analysis}

Data gathered from the questionnaire were analysed by using the SPSS software. This was followed by measures of central tendency and location (mean and sum) for understanding the important features of the stages of the e-commerce platform in the development of home delivery of portable petroleum refuellers.

Table 2: Demographic Profile

\begin{tabular}{|c|c|c|}
\hline \multicolumn{3}{|c|}{ Qualification } \\
\hline Particular & Frequency & Percent \\
\hline Below Graduation & 18 & $13.8 \%$ \\
\hline Graduation & 50 & $38.5 \%$ \\
\hline Post Graduation & 38 & $29.2 \%$ \\
\hline Others & 24 & $18.5 \%$ \\
\hline Total & 130 & $100.0 \%$ \\
\hline \multicolumn{3}{|c|}{ Age } \\
\hline Particular & Frequency & Percent \\
\hline $18-28$ & 43 & $33.1 \%$ \\
\hline $28-38$ & 38 & $29.2 \%$ \\
\hline $38-48$ & 22 & $16.9 \%$ \\
\hline $48-58$ & 17 & $13.1 \%$ \\
\hline above 58 & 10 & $7.7 \%$ \\
\hline Total & 130 & $100.0 \%$ \\
\hline \multicolumn{3}{|c|}{ Gender } \\
\hline Particular & Frequency & Percent \\
\hline Male & 64 & $49.2 \%$ \\
\hline Female & 66 & $50.8 \%$ \\
\hline Total & 130 & $100 \%$ \\
\hline
\end{tabular}

Source: Primary Data Analysis 
Out of 130 respondents, $13.8 \%$ were 'Below graduation', 38.5\% were in the category of 'Graduation', 29.2\% under 'Post Graduation', and $18.5 \%$ under 'Others'. Amongst the respondents, $33.1 \%$ fall under the age group of $18-28,29.2 \%$ were between the age group of $28-38,16.9 \%$ were between the age group of $38-48$, $13.1 \%$ were between the ages of $48-58$ whereas the remaining $7.7 \%$ were above the age group of 58 years. There were $49.32 \%$ male respondents and $50.8 \%$ female respondents.

$\mathrm{H} 0$ : there is no significant difference between age and contemporary scope on home delivery portable petroleum in the ecommerce platform.

Table 3: ANOVA

\begin{tabular}{lrrrrr}
\hline & $\begin{array}{c}\text { Sum of } \\
\text { Squares }\end{array}$ & df & $\begin{array}{c}\text { Mean } \\
\text { Square }\end{array}$ & F & Sig. \\
\hline Between Groups & 94.552 & 4 & 23.638 & .852 & .495 \\
Within Groups & 3468.556 & 125 & 27.748 & & \\
Total & 3563.108 & 129 & & & \\
\hline
\end{tabular}

Source: Primary Data

Since $\mathrm{H} 0$ is greater than 0.05 , the null hypothesis was rejected. The Anova test concludes that there is a significant difference between age and contemporary scope on home delivery portable petroleum in the e-commerce platform.

Furthermore, the Chi-Square test was performed on the data below. H0: There is no association between occupations and preference of home delivery of petroleum products.

Table 4: Chi-Square Test

\begin{tabular}{llrrrr}
\hline Particulars & & \multicolumn{3}{c}{$\begin{array}{c}\text { Preference for home delivery } \\
\text { of petroleum products }\end{array}$} & Total \\
& & Yes & No & Maybe & \\
\hline Qualification & Below & 5 & 1 & 2 & 8 \\
& $\begin{array}{l}\text { Graduation } \\
\text { Graduation }\end{array}$ & 27 & 15 & 8 & 50 \\
& $\begin{array}{l}\text { Post } \\
\text { Graduation }\end{array}$ & 21 & 31 & 16 & 68 \\
& others & 2 & 0 & 2 & 4 \\
Total & & 55 & 47 & 28 & 130 \\
\hline
\end{tabular}


Table 5: Chi-Square Tests

\begin{tabular}{lrrr}
\hline & Value & df & Asymp. Sig. (2-sided) \\
Pearson Chi-Square & 11.809 & 6 & .066 \\
\hline
\end{tabular}

Source: Primary Data

Since H0 is greater than 0.05 , the null hypothesis was rejected. Therefore, there is a relationship between occupation and preference of customer over home delivery of petroleum product.

Table 6: Factor Analysis Test - Total Variance explain the factors that challenge or risks factors on e-commerce over Petroleum Products with Portable Refuellers

\begin{tabular}{|l|c|c|c|c|c|c|}
\hline \multirow{2}{*}{$\begin{array}{c}\text { Com- } \\
\text { ponent }\end{array}$} & \multicolumn{3}{|c|}{ Initial Eigenvalues } & \multicolumn{3}{c|}{$\begin{array}{c}\text { Extraction Sums of } \\
\text { Squared Loadings }\end{array}$} \\
\cline { 2 - 7 } & Total & $\begin{array}{c}\text { \% of } \\
\text { Variance }\end{array}$ & $\begin{array}{c}\text { Cumulative } \\
\%\end{array}$ & Total & $\begin{array}{c}\text { \% of } \\
\text { Variance }\end{array}$ & $\begin{array}{c}\text { Cumulative } \\
\%\end{array}$ \\
\hline 1 & 3.902 & 27.873 & 27.873 & 3.902 & 27.873 & 27.873 \\
\hline 2 & 1.973 & 14.092 & 41.965 & 1.973 & 14.092 & 41.965 \\
\hline 3 & 1.682 & 12.011 & 53.976 & 1.682 & 12.011 & 53.976 \\
\hline 4 & 1.186 & 8.469 & 62.445 & 1.186 & 8.469 & 62.445 \\
\hline 5 & .971 & 6.938 & 69.383 & & & \\
\hline 6 & .784 & 5.598 & 74.981 & & & \\
\hline 7 & .730 & 5.215 & 80.196 & & & \\
\hline 8 & .699 & 4.996 & 85.193 & & & \\
\hline 9 & .559 & 3.992 & 89.185 & & & \\
\hline 10 & .539 & 3.852 & 93.037 & & & \\
\hline 11 & .440 & 3.142 & 96.179 & & & \\
\hline 12 & .307 & 2.192 & 98.372 & & & \\
\hline 13 & .228 & 1.628 & 100.000 & & & \\
\hline Extraction Method: Principal Component Analysis. & & \\
\hline Source: Primary data &
\end{tabular}


Table 7: Results of Rotated Component Matrix for the factors that challenge or risks factors on e-commerce over Petroleum Products with Portable Refuellers

\begin{tabular}{|c|c|c|c|c|c|}
\hline \multirow[t]{2}{*}{ S.No } & \multirow[t]{2}{*}{ Variables } & \multicolumn{4}{|c|}{ Factor Loadings } \\
\hline & & 1 & 2 & 3 & 4 \\
\hline 1 & Intellectual product & .730 & & & \\
\hline 2 & Risk of explosion & .655 & & & \\
\hline 3 & mishandle & .642 & & & \\
\hline 4 & spamming & .520 & & & \\
\hline 5 & Precaution management & 412 & & & \\
\hline 6 & Environment issues & & .563 & & \\
\hline 7 & Negligence accident & & 339 & & \\
\hline 8 & overcharge & & .056 & & \\
\hline 9 & Inefficiency delivery & & & .663 & \\
\hline 10 & Longer delivery time & & & .443 & \\
\hline 11 & Safety hazards & & & .392 & \\
\hline 12 & $\begin{array}{l}\text { Lack of awareness to } \\
\text { handle the technology }\end{array}$ & & & 316 & \\
\hline 13 & Logistic dilemma & & & & $\begin{array}{r}.44 \\
9\end{array}$ \\
\hline 14 & Congestion of traffic & & & & $\begin{array}{r}.32 \\
4\end{array}$ \\
\hline 15 & Price fluctuation & & & & $\begin{array}{r}.10 \\
9\end{array}$ \\
\hline
\end{tabular}

Source: Primary data

The above table explains the percentage of variance explained in each of the derived factor elements towards challenges or risk factors on e-commerce of petroleum products with portable refuellers. The factors are divided into four levels based on the intensity of risks possessed by the portable refuellers. High risks contain factors like risk of explosion, mishandle, spamming, precaution management whereas factors like environment issues, accidents due to negligence, overcharge are second in line. Further, inefficient delivery, longer delivery time, safety hazards, lack of awareness to handle the technology are some other features that rank third in the list of risks possessed by portable petroleum. Lastly, factors such as logistics dilemma, congestion of traffic, price 
fluctuation and so on are the least affecting factors of portable petroleum refuellers.

\section{Findings from the Study}

Since the null hypothesis is rejected in the ANOVA test, it is implied that there is a relationship between age and contemporary scope on home delivery portable petroleum in e-commerce platforms. Likewise, there is also a relationship between occupation and the preference for home delivery in petrol outlets. The factor analyses have explained the various risks of this modern technology which have been categorized into high, low, and medium in terms of their market feasibility.

\section{Conclusion}

The study concludes that the scope for portable petroleum phenomena with the home delivery facility is quite promising, and the future generation who are technologically advanced can make the most out of this concept. The important dimensions of portable petroleum are the acceptability of technology and customer satisfaction. The new technology comes with certain restrictions and risk factors, which if not treated seriously in the initial stages might lead to the failure of the innovation.

\section{Scope for Future Research}

This study is limited to portable petroleum products. The study can be carried out for other relatable product in the same arena. A comparative study on the attitude of customers towards awareness and willingness to embrace hybrid vehicles and electronic vehicles can be taken up. A comparative study can be made between the efficiency in the performance of liquefied petroleum gas cylinder and petroleum liquid and performance and price effectivity.

\section{References}

Kumar, C., \& Prasad, S. (2017, June 22). India Inc breaks unwritten rule, lends voice to campaign Retrieved from http://timesof india. indiatimes.com / articleshow/ 59261768.cms? 
utm_source $=$ contentofinterest\&utmmedium text\&utm campaign cppst.

Kavitha, G., \& Mary, J.S.A. (2018). A study on customer perception towards service quality of retail petrol outlets. EPRA International Journal of Economic and Business Review, 6(7), 11-16. Retrieved from https:/ / eprawisdom.com/jpanel/upload/articles/723am2.Dr.(Mrs).

G.Kavitha\%20\&\%20J.Sagaya\%20Anglien\%20Mary.pdf

Kumari, R.K., \& Devi, N. Y. (2016). A study on consumer behavior towards retail petrol outlet services in Coimbatore city. International Journal of Applied Research, 2(2), 670-673.

Jacob, S. (2017, June 9). Petrol, diesel home delivery: Soon, fuel at your doorstep on online booking Retrieved from https://www.businessstandard.com/article/economy-policy/ petrol-diesel-home-deliverysoon-fuel-at-your-doorstep-on-online-booking-117042100670_1.html

ZeeBizWebTeam. (2018, March 27). Now get fuel delivered to your doorstep; all you need to know. Retrieved from https:/ / www.zeebiz.com/india/news-now-get-fuel-delivered-toyour-doorstep-all-you-need-to-know-40673 